\title{
COMPLIANCE AND RULE-FOLLOWING UNDER LEGAL UNCERTAINTY: TOWARDS A THEOLOGY- INSPIRED NEW LEGAL CASUISTRY
}

Summary: $\quad$ A modern theory of casuistry has not been developed or paid much attention to in legal scholarship in Europe lately, since the partial failure of Viehweg to reintroduce the casuistic (topical) approach in 1950s. Yet, the related problems have not withered away and even today many legal professionals (attorneys and judges alike) still face the same dilemmas as already the medieval confessors and casuists did. This contribution thus ponders upon the question as to whether any new solid theory of legal casuistry - building either on the casuistry employed by theologians and confessors, or casuistry employed nowadays by ethicists, especially in bioethics - can be helpful to modern continental lawyers, who are used rather to systematic instead of casuistic thinking, but still either doubt the one-right-answer theory, or find themselves in a situation of legal uncertainty for whichever reason.

Keywords: $\quad$ topics, casuistry, moral theology, compliance, uncertainty

\section{INTRODUCTION}

The topic of mutual interrelationship between religion and law has been in the centre of attention of Western European and US legal historians for quite some time. It is thereby claimed that in the period starting from 1500, a peculiar combination of law and religion occurred, manifested in an explosion of treatises on moral theology, in which law and theology were closely intertwined. Indeed, members of various Catholic monastic orders authored treatises on legal issues approached from a theological, religious point of view. Thereby, mostly the issues of procedural law and contract law were seen as those that the moral theology was interested in, claiming that any confessor must take positive law into account when guiding the

Prof. JUDr. PhDr. Tomáš Gábriš, PhD, LLM, MA, researcher, Slovak Academy of Sciences, Institute of State and Law, Klemensova 19, 81364 Bratislava, Slovak Republic. E-mail address: gabris.tomas@gmail.com. ORCID: https://orcid.org/0000-0002-68622688. 
faithful members of the church in their everyday lives and legal problems. A good moral theologian was thus to efficiently employ the tools of secular law within the practice of confession, but also generally in solving any possible situations where religious and legal issues collided.

One of the so far neglected "legal" problems that moral theologians (confessors) often faced in their practice, was the issue of legal uncertainty. Namely, the Scripture itself, as well as confession manuals and the secular law on which the confessors were giving advice, were far from complete, clear, unequivocal, and covering all possible situations that a daily life could bring. Thus, in modern terms, problems arose as to how to ensure compliance and rule-following in situations of legal (as well as moral, religious) uncertainty. A number of theories was proposed by experts in moral casuistry already in the Middle Ages, later categorized as the theories of tutiorism, probabilism, probabiliorism, equiprobabilism and others.

Currently, legal theory and legal practice are facing a similar problem - of the one-right-answer theory, especially in "hard cases"? If there is only one right answer (as Dworkin claimed), ${ }^{1}$ how to reach or predict the correct answer - specifically if neither judges nor attorneys are Herculeses and attorneys need to advise their clients way before one hears the final answer from the court? And if there is not only one correct answer (as legal realists claim²), how to at least minimize the risks of breach/illegality, and to ensure the possibly highest standard of compliance? In any case, in both strands the same question arises - how to methodologically approach a legal problem from the bottom up, in a casuistic manner?

A modern theory of casuistry has not been developed or paid much attention to in legal scholarship in Europe lately, since the partial failure of Viehweg to re-introduce the casuistic (topical) approach in 1950s. Yet, the related problems have not withered away and even today many legal professionals (attorneys and judges alike) still face the same dilemmas as already the medieval confessors and casuists did. This contribution will thus ponder upon the question as to whether any solid theory of new legal casuistry - building either on the casuistry employed by confessors, or casuistry employed nowadays by ethicists, especially in bioethics - can be of help to modern continental lawyers, used rather to systematic instead of casuistic thinking, but still either doubting the one-right-answer theory, or finding themselves in a situation of legal uncertainty for any other reason. Based on early modern moral theology and its theories of casuistry, this paper will offer both descriptive and prescriptive views on the use and potential benefits of a new theory of casuistry in legal theory and legal practice. The paper can thus be seen as a contribution to the dispute between systematic approach to law (being questioned nowadays by legal realists and post-positivists in general), and problem-based approach to law, also known under the heading of casuistic, topical or rhetorical (argumentative) approach to law. Their possible combination in order to solve the hard cases will be considered in this paper as a sort of new legal casuistry applicable in the post-positivist era.

1 See in detail Aarnio, A., One Right Answer? In: Aarnio, A., Essays on the Doctrinal Study of Law, Springer, Dordrecht, 2011, pp. 165-166.

2 Barberis, M., El realismo jurídico europeo-continental. In: Fabra Zamora, J. L.; Núñez Vaquero, Á. (eds.), Enciclopedia de Filosofía y Teoría del Derecho, volumen uno, UNAM, Mexico, 2015; Ferrer Beltrán, J.; Ratti, G. B. (eds.), El realismo jurídico genovés. Marcial Pons, Madrid, 2011. 


\section{BASIC NOTIONS - COMPLIANCE AND RULE-FOLLOWING, UNCERTAINTY, CASUISTRY}

The key problems mentioned already in the very title of this paper are those of compliance, rule-following, uncertainty and casuistry. After offering their definitions for the purposes of this contribution, the basic research question of this paper will be approached - that of importance of casuistry in the post-modern, post-positivist legal situation, where numerous factors pose challenge to the traditional positivist and formalist approach to law. It will be argued that casuistry, built upon the foundations laid down by medieval and early modern moral theologians, can be used as a model for explanation and possibly also as a guide for legal professionals in solving "uncertain" (hard) cases even nowadays.

To start now finally with the key notions and problems from the title of this contribution, let us explain here that compliance is a notion and issue of making sure that all legal obligations are being complied with, including setting the inner procedures within an entity in such a way as to minimize the risk of liability of the entity. Besides this practical, dogmatic context, in legal philosophy, this notion is traditionally invoked in a broader context of rule-following (in the very meaning of following rules), popular foremost among analytical (legal) philosophers. ${ }^{3}$ In this paper, compliance will be perceived in its common-language meaning of ensuring the harmony with law, with legal norms.

The second notion, that of uncertainty, is especially popular nowadays among the scholars of the Law \& Economics movement and foremost among the scholars of behavioural economics and law. These authors namely claim that uncertainty in legal context may sometimes be beneficial - namely, if risk is too high, the entities usually go for a less risky option when choosing between two possible alternatives. ${ }^{4}$ These approaches are, however, rather popular in the US; in Europe, uncertainty is a topic treated instead within the movement of current legal realism (e.g., R. Guastini, ${ }^{5}$ M. Troper ${ }^{6}$ ), emphasizing both uncertainty of rules as well as of facts, just like American legal realists, such as Jerome Frank, did already decades ago.

3 Berdisová, L., Objectivity and arbitrariness of blind rule-following or what it means to follow a (legal) rule blindly. In: Breda, V.; Rodak, L. (eds.), Diverse Narratives of Legal Objectivity: an interdisciplinary perspective, Peter Lang, Frankfurt am Main, 2016, pp. $29-56$.

4 Lang, M., Legal uncertainty as a welfare enhancing screen, European Economic Review, 91, 2017, p. 275: "The literature has considered both costs and benefits of legal uncertainty. Legal uncertainty reduces deterrence and makes it more difficult or impossible to achieve optimal deterrence. For example, Polinsky and Shavell (1989) demonstrate that legal uncertainty lowers deterrence, because expected sanctions are reduced and less suits are brought to court." However, "beneficial effects of legal uncertainty have appeared in several specific contexts. They show that uncertainty about enforcement might have beneficial deterrence effects." (Ibid., p. 276). "Suppose that the threshold of legality is not specified exactly. In addition, there is asymmetric information between firms and enforcement authorities. The enforcement authority cannot observe firms' private benefits of an action. With legal certainty, hence, firms decide independently of the action's private benefits whether to take the action. With legal uncertainty, the probability of conviction depends on the distance to the threshold of legality and whether the firm is above or below the threshold. If a firm is close to, but below the threshold, there is some probability of being convicted. Therefore firms with low private benefits do not take the action. Legal uncertainty deters them. If a firm is close to, but above the threshold, there is some probability of not being convicted. Hence firms with high private benefits take the action. Legal uncertainty encourages them to take the action. Both effects increase social welfare independently of underlying distributions. The effects are also robust to random audits, alternative penalties and different welfare standards. Consequently, some legal uncertainty about the threshold of legality increases welfare." (Ibid., p. 282).

5 Guastini, R., A Sceptical View on Legal Interpretation. In: Analisi e diritto 2005. Giappichelli, Turin, 2006.

6 Glučina, I., Michel Troper i francuski pravni realizam. In: Zbornik radova Pravnog fakulteta u Splitu, god. 53, 3/2016, pp. 777796; Champeil Desplats, V., Michel Troper (1938- ). In: Pattaro, E.; Roversi, C. (eds.), A Treatise of Legal Philosophy and General Jurisprudence. Volume 12. Legal Philosophy in the Twentieth Century: The Civil Law World, Springer, Dordrecht, 2016, p. $447 \mathrm{ff}$. 
Uncertainty in this context operates with the rejection of one-right-answer theory ${ }^{7}$ and with the acknowledgment of under-determination of law, legal system being considered inherently porous, vague, and not offering the sole one right answer, specifically in hard cases. ${ }^{8}$

Finally, the notion of casuistry is currently popular especially in ethics (in fact, already since Aristotle), being considered a third possible approach besides utilitarianism (consequentialism - in legal scholarship recognized and invoked by the already mentioned L\&E movement in common law countries, where judges are to take into account the consequences of their decisions) and principlism (in legal scholarship invoked e.g. by Dworkin and Alexy, both recommending the procedure of balancing of principles). The third approach in ethics - casuistry - is nowadays popular foremost in bioethics. Being a bottom-up, problem-based approach, this makes it similar to the topical approach in law elaborated in mid-20th century predominantly by Viehweg and in rhetorical contexts also by Perelman.

In present-day scholarship, with the popular theory of practical (phronetic) science giving guidelines for decision-making in social sciences (e.g. in the works by Flyvbjerg ${ }^{9}$ ) there is again a chance for revival of this sort of approach not only in ethics, where casuistry was elaborated in detail by Jonsen and Toulmin at the end of the 20th century, but also in legal scholarship and in legal practice - foremost with regard to solving hard cases, where no prior clear rule or regulation was given by legislator. In such cases, application of law indeed has to rely on phronesis (wisdom acquired through practical experience) and possibly on maxims/paradigms (enshrining the practical wisdom), which was a characteristic feature of the topical and casuistic approach to law in continental Europe up to 17th century, since when casuistry was gradually replaced by a systematic approach to law, based on interpretation of legal norms enshrined in legislative texts. ${ }^{10}$

\section{SIMILARITIES BETWEEN LAW AND ETHICS}

The return to casuistry in ethics is mostly connected with names of Albert Jonsen and Stephen Toulmin ${ }^{11}$ who authored their 1988 book "The Abuse of Casuistry". Many authors since then realized the relationship between casuistry and law, specifically in common law systems, causing John Arras to even call casuistry "morisprudence" or "common law morality".12 Still,

7 Aarnio, op. cit., note 1, pp. 165-166. See also Sinai, Y.; Golding, M. P., Is there only One Correct Legal Answer to a Question of Fact? Three Talmudic Answers to a Jurisprudential Dilemma, Ratio Juris, Vol. 29, No. 4, 2016, pp. 478-505.

8 In addition to works of the above-mentioned Riccardo Guastini and Michel Troper, see also Dari-Mattiacci, G.; Deffains, B., Uncertainty of Law and the Legal Process, Journal of Institutional and Theoretical Economics, 163, 2007, pp. 628-629: "We employ the notion of uncertainty of law to refer to the fact that it is difficult to predict perfectly ex ante how the law will be applied ex post by the courts. ... theft of electricity was problematic in more than one legal system in the late nineteenth century, as it was not clear whether electricity qualified as an asset as defined by the law of theft."

9 Flyvbjerg, B., Making Social Science Matter: Why Social Inquiry Fails and How It Can Succeed Again, Cambridge University Press, Cambridge, 2001.

10 Schröder, J., Recht als Wissenschaft : Geschichte der juristischen Methodenlehre in der Neuzeit (1500-1933), 2nd ed., C.H.Beck, München, 2012.

11 Jonsen, A. R.; Toulmin, S., The Abuse of Casuistry: A History of Moral Reasoning, University of California Press, Berkeley, 1988. 
its applicability in the context of continental European legal systems still awaits its re-assessment, at which this contribution is but an introductory attempt.

To ponder upon benefits of legal casuistry for continental Europe, it is important to recall first that Jonsen and Toulmin employed casuistry as a mechanism to solve ethical problems based on analogical reasoning mostly. They developed their "new casuistry" being largely inspired by Jesuit casuistry, while introducing three new casuistic categories: taxonomy, morphology, and kinetics (to be introduced infra). In contrast, Viehweg's attempt at revival of casuistry in law completely omitted the moral theology and its casuistry, which may be considered a mistake to be compensated for in this paper.

Still, before embarking on this journey, it is necessary to place the casuistic approach next to its rival concepts of principlism (deontology) and utilitarianism (consequentialism), representing three basic types of ethical (possibly also jurisprudential) theories. ${ }^{13}$ Out of these three, consequentialism is based on top-down reasoning, consisting in using an abstract principle to be applied in practice, evaluating thereby the consequences of its application (similarly as known and applied in jurisprudence, specifically in the Law \& Economics movement). Casuistry, in contrast, uses a bottom-up reasoning, searching for more abstract rules to solve a particular problem (case), without applying or invoking any principles. Finally, principlism is allegedly a compromise between the former two approaches. ${ }^{14}$ Its main methods are claimed to be specification and balancing, similar to weighing of principles recognized in legal scholarship. However, in situations where principles or norms (rules) are absent, or the issue is rather technical, not enshrining or compromising prima facie any values or principles, none of the top-down approaches can be of use here; then, preference should be given to the approach based on bottom-up (casuistic) elements.

These elements are thereby the following, as proposed by Toulmin and Jonsen: "(1) the reliance on paradigms and analogies, (2) the appeal to maxims, (3) the analysis of circumstances, (4) the degrees of probability, (5) the use of cumulative arguments, and (6) the presentation of a final resolution". ${ }^{15}$ In addition to these six elements, three concepts of taxonomy (sub 1 and 2), morphology (sub 3 and 4) and kinetics (sub 5 and 6) also play a role in Toulmin and Jonsen's theory of casuistry, claiming to provide a step-by-step guidance to resolution of any specific case: ${ }^{16}$

The morphology is namely claimed to work with the notions of the "center of a case" and "circumstances that stand around the center", whereby the center is "constituted of certain maxims, brief rule-like sayings that give moral identity to the case ... [Maxims] distill, in a pithy way, experience" ${ }^{17}$ Maxims are thereby claimed to be different from the more abstract paradigms. E.g., if a paradigm is the general prohibition of killing, a maxim might be a saying such as "force may be repulsed by force". ${ }^{18}$ The maxims are thus similar to the topoi in topical approach

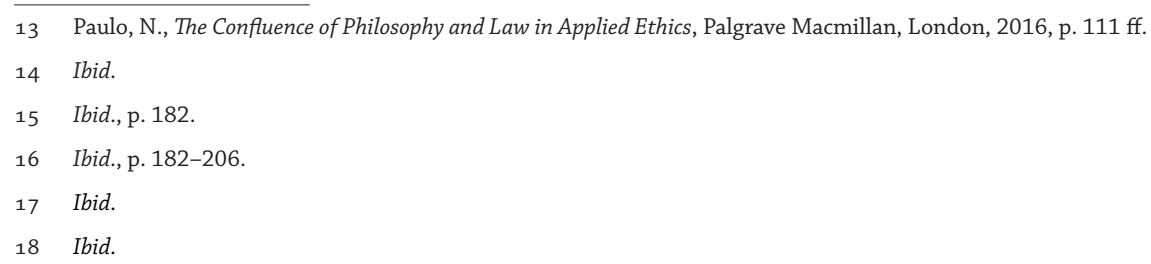


to law (and ethics) and serve as the loca of certitude, based on which the arguments can be construed, and a final decision reached.

The taxonomy is then perceived as the "lining up of cases in a certain order" ${ }^{19}$ E.g., in case of killing, the line starts with unprovoked killing, then moving to less certain cases, e.g. cases of physician-assisted suicide. The rule is thereby to start with the "most manifest breaches of the general principle, taken in its most obvious meaning [and then to propose cases that move] away from the paradigm by introducing various combinations of circumstances and motives that [make] the offense in question less apparent". ${ }^{20}$ Still, often, conflicting paradigms must be reconciled. However, this is different from balancing principles known in jurisprudence. Weighing of principles within the principlist approach both in ethics and jurisprudence namely resolves the case by itself, while identifying a particular paradigm ${ }^{21}$ still offers no final solution to the case, Jonsen and Toulmin claim. ${ }^{22}$

It is only within the so-called kinetics, where "the circumstances get fitted to other important social institutions or personal ideals", ${ }^{23}$ that "relevant features get quantified and weighed in order to resolve the case" ${ }^{24}$ However, this may seem quite an unclear place in Jonsen's and Toulmin's theory of casuistry, lacking proper guidelines and thus raising doubts as to the overall concept of morphology, taxonomy, and kinetics in their "new" casuistry and as to its applicability in legal practice in continental Europe.

This is perhaps the point where maybe a simpler and more instructive directive could be construed with resort back to the origins of the modern casuistry found in moral theology, thus compensating for deficiencies of Toulmin and Jonsen's theory, making it more apt to provide guidance for legal professionals in the post-positivist situation where many issues and instances are perceived as not regulated by legislator, or regulated in an unsatisfactory manner. In such situations, an answer might be provided precisely through a compromise between systematic and problem-based thinking (Problemdenken), meaning at the same time a compromise between principlism and casuistry, moving slightly towards the topical/casuistic approach to law, albeit only in some specific situations where principlism and traditional formalist approach to law are not of help. Viehweg's topical approach, if supplemented by elements from the theory of moral casuistry (disregarded by Viehweg in his version of legal topics) might thus provide for a recipe to find answers to hard cases as well as explain how the law actually works in its post-positivist or phronetic version. Finally, last but not least, at the same time this could also be a piece of evidence on actual merging and mixing of continental law and common law (case-based) legal families - due to the greater emphasis being placed on judicial decision-making in specific cases besides the applicability of general rules and norms.

\footnotetext{
19 Paulo, op. cit., note 12, p. 375.

20 Paulo, op. cit., note 13, p. $183 \mathrm{ff}$.

21 Casuists claim that paradigms "are rules that are more abstract than maxims; they are paradigmatic instances of rightness or wrongness. Examples for paradigms are sexual abuse of children, gratuitous care of the impoverished sick, and the general prohibition of killing." See ibid., p. 194.

22 Ibid., pp. 189-190.

23 Paulo, op. cit., note 12, p. 376.

24 Paulo, op. cit., note 13, pp. 190-191.
} 


\section{MORAL THEOLOGY AND MORAL CASUISTRY}

The topic of mutual interrelationship between religion/theology and law has been in the centre of attention of Western European and US legal historians for quite some time. ${ }^{25}$ It suffices to mention the names of authors such as H. Berman, ${ }^{26} \mathrm{~W}$. Decock, ${ }^{27}$ or J. Witte. ${ }^{28}$ From among German-speaking (legal) historians it was e.g. Peter Landau, who wrote extensively on the influence of Catholic Church and canon law on the legal thought of medieval ${ }^{29}$ as well as early modern continental Europe. Recently, the topic was covered e.g. by M. Schmoeckel and his collaborators. ${ }^{30}$ Besides catholicism and canon law, protestantism was also paid attention to in this context, mostly in connection with the idea of Max Weber on protestantism and secularization as basic sources of modern society and modern law. ${ }^{31} \mathrm{In}$, fact, specifically Calvinism is said "to have attracted some of the most innovative jurists of the early modern period", ${ }^{32}$ influencing thus legal thought in Europe in general.

All in all, both in catholic as well as in protestant countries, it is claimed by legal historians that in the period starting from 1500, an unprecedented synthesis of law and religion in the texts on moral theology took place. Some have denoted the closely related explosion of treatises on moral theology as a "second canon law", whereby mostly the issues of procedural law and contract law ${ }^{33}$ were seen as those that the catholic moral theology was interested in, ${ }^{34}$ when guiding the faithful members of church in their everyday lives and through their legal problems. A confessor was claimed to be obliged to apply secular law even in matters of conscience,

25 On the "theological turn", see e.g. David, J. E., Jurisprudence and Theology in Late Ancient and Medieval Jewish Thought, Springer, Cham, 2014.

26 Berman, H., Law and Revolution. The Formation of the Western Legal Tradition, Harvard University Press, Cambridge Mass., 1983; Berman, H., Law and Revolution II: The Impact of the Protestant Reformations on the Western Legal Tradition, Harvard University Press, Cambridge Mass., 2003.

27 Decock, W., From Law to Paradise: Confessional Catholicism and Legal Scholarship, Rechtsgeschichte, 18, 2011.

28 Witte, J., Law and Protestantism: The Legal Teachings of the Lutheran Reformation, Cambridge University Press, Cambridge, 2002.

29 Bunge, K.; Fuchs, M. J.; Simmermacher, D.; Spindler, A. (eds.), The Concept of Law (lex) in the Moral and Political Thought of the 'School of Salamanca', Brill, Leiden, 2016.

30 Schmoeckel, M.; Condorelli, O.; Roumy, F. (eds.), Der Einfluss der Kanonistik auf die europäische Rechtskultur. Bd. 1: Zivil- und Zivilprozessrecht, Böhlau Verlag, Köln, 2009; Roumy, F.; Schmoeckel, M.; Condorelli, O. (eds.), Der Einfluss der Kanonistik auf die europäische Rechtskultur, Bd. 2: Öffentliches Recht, Böhlau Verlag, Köln, 2011; Schmoeckel, M.; Condorelli, O.; Roumy, F. (eds.), Der Einfluss der Kanonistik auf die europäische Rechtskultur, Bd. 3: Straf- und Strafprozessrecht, Böhlau Verlag, Köln, 2012; Mausen, Y.; Condorelli, O.; Roumy, F.; Schmoeckel, M. (eds.), Der Einfluss der Kanonistik auf die europäische Rechtskultur, Bd. 4: Prozessrecht, Böhlau Verlag, Köln, 2014; Schmoeckel, M., Das Gesetz Gottes als Ausgangspunkt christlicher Ethik? Zu calvinistischen Traditionen des 16. Jhs im Hinblick auf ihre rechtshistorische Relevanz, Ius commune, 25, 1998, pp. 347-366; Schmoeckel, M., Die katholische Wissenschaft. Die methodische Säkularisation der Jurisprudenz im 16. Jahrhundert. In: Büttgen, P.; Imbach, R.; Schneider, U. J.; Selderhuis, H. J. (eds.), Vera Doctrina. Zur Begriffsgeschichte der Lehre von Augustinus bis Descartes, Harrassowitz Verlag, Wiesbaden, 2009, pp. 167-171.

Weber, M., The Protestant Ethic and the Spirit of Capitalism, Routledge, London and New York, 1992; Likhovski, A., Protestantism and the rationalization of English Law: A Variation on a Theme by Weber, Law \& Society Review, 1999, 33, 2, p. 365 ff.

32 Decock, op. cit., note 27, p. 12.

33 Decock, W., Jesuit Freedom of Contract, The Legal History Review, 77, 2009, pp. 423-458; Decock, W., Theologians and Contract Law: The Moral Transformation of the Ius Commune (ca. 1500-1650), Brill, Leiden, 2014.

34 Whitman, J. Q., The origins of reasonable doubt, theological roots of the criminal trial, Yale University Press, New Haven, London, 2008. 
provided it is in harmony with natural law. ${ }^{35}$ This specific situation influenced the subsequent legal history, many secular jurists quoting the theologians, ${ }^{36}$ just like the theologians were invoking the treatises of secular lawyers.

The confessors were indeed not far from judges or lawyers. Even in their terminology, they clearly used "legalese" - e.g., claiming that lighter sins go praeter legem, while more serious sins mean acting contra legem. ${ }^{37}$ A confessor, resembling a judge, soon realized he needed his "law-code" - and that is precisely how the rise of so-called confessor manuals took place. In fact, already in 7th to 12th centuries, there were books of penitence used, providing lists of sins with appropriate punishment, penance. From the 13th century onwards, when the 4th Lateran council introduced the obligation to undertake a confession at least once a year, the books of penitence started to be replaced by newer confessor manuals. ${ }^{38}$ These can be divided into two groups - of confessor summae, which were more legal in their nature, and of simpler confession manuals. The model for the first group was the summa of Raymund of Peñaforte from 1220-1240. His Summa de casibus poenitentiae became so popular that it was published in many abridged versions and in the 15th century it was even rendered in a poetic version, while its author was canonized in 1601. Similar summae quickly spread across the continent - they were used in Spain, Germany, France, and Italy. The most important ones included: Summa confessorum (cca 1290) by Joannes of Freiburg, Summa de poenitentia (1295-1302) by Joannes of Erfurt, later remastered by Durandus de Champagne, Summa Astesana (cca 1317) by Astesanus of Asti, Summa de casibus conscientiae (1338) by Bartolomaeus of Pisa (therefore called also Pisanella), and Supplementum to Pisanella, written by Nicoló d'Ausimo. All of these summae and their authors emphasized the legal aspects in their works, quoting secular lawyers and using the binary categories of legal and illegal in terms of human behaviour and sin.

After a slight decline during the times of papal schism, the summae regained their popularity around the year 1500, when new summae were published by Battista de Salis (1480-1490), Angelo de Chiavasso (in the same decade), Sylvester Prierias (cca 1516), Giovanni Cagnazzo of Taggia (1517) and Cajetanus (1525). With the exception of Cajetanus, all the summae were again very much leaning on legal terminology. E.g. Prierias himself claims that in his Summa summarum he excerpted works of 48 theologians, 113 lawyers and18 authors of various summae. Giovanni Cagnazzo reports to have used even $20 \%$ more sources. ${ }^{39}$ The legal aspects were emphasized in the summae even after the Trident council (1545-1563) with the birth of "new

35 E.g., by Martin de Azpilcueta (1492-1586), also known as Dr. Navarrus, the author of Enchiridion or Manual for Confessors and Confessants (Manuel de confessores y penitentes) (1552). Francisco de Toledo (1532-1596) authored Instruction for Priests and Penitants (Instructio sacerdotum ac poenitentium) in 1596, Valère Regnault (1549-1623) published his Praxis fori poenitentialis (in 1616), Paul Laymann (1574-1635) wrote five books on Moral Theology, Vincenzo Figliucci (1566-1622) published his Quaestiones morales, Hermann Busenbaum (1600-1668) authored Medula theologiae moralis, and Joseph Gibalin (1592-1671) wrote the book De universa rerum humanarum negotiatione tractatio scientifica (1663), focussing specifically on commerce and contracts. Finally, worthy mentioning is also Ignaz Schwarz (1690-1763) who published his Institutiones iuris publici universalis as a reply to the natural law treatises of Grotius, Pufendorf, Thomasius, Vitriarius and Heineccius. See in more detail Decock, op. cit., note 27 , pp. 28-29.

36 Ibid., p. 34.

37 Delumeau, J., Sin and Fear: The Emergence of the Western Guilt Culture, 13th-18th Centuries, Palgrave Macmillan, London, 1990.

38 Ibid.

39 Similarly, "two thirds of the references contained in (Angelo Carletti's) Summa Angelica were taken from Roman law, canon law and medieval jurists". See Decock, Theologians, op. cit., note 33, p. 44. 
casuistry" when besides quoting medieval lawyers, emphasis began to be placed also on morals, conscience and various sorts of mitigating circumstances. ${ }^{40}$

It is thereby argued that the summae for confessors provided one of the highways through which the ius commune actually took root in European society. In addition, the popular literature of theologians such as Soto, Molina and Lessius, allegedly also contributed much to the diffusion of the texts of the ius commune and to their preservation as a repository of legal vocabulary and legal argument until the modern era, ${ }^{41}$ influencing thus the modern legal thought. In this paper, however, we shall not be interested much in the nature and importance of works by theologians such as Soto or Molina. Instead, we shall concentrate on the issues common to catholics and protestants alike - the casuistry. Indeed, the ongoing presence of catholic moral casuistry even in 17th century reformed circles is obvious, e.g. from juridical dissertations supervised by the theologian and jurist Samuel Stryck (1640-1710), the jurist Christian Thomasius (1655-1728) and the protestant professor of natural law Samuel von Pufendorf (1632-1694). ${ }^{42}$

To explain here at least a little the various forms and branches of moral casuistry in order to assess its possible use in present days jurisprudence, it is important to note that numerous competing theories of casuistry emerged with the time, actually leading in the final effect to the decline of casuistry as such. Let us start with two extreme positions in guiding a decision-maker or an agent:

One of the most popular thereby was the doctrine claiming that if a practical opinion or counsel is probably true, it is permitted to follow it, even though it is more probable that the opposite opinion is true. This thesis, subsequently labelled as "probabilism", was first enunciated by Bartolomeus Medina in 1577. Hitherto, the predominant view had been instead that where there were divergent opinions on how to act, differing in their likelihood of being correct, the path of prudentia (practical reason) was to follow the more probable opinion. This was the via tutior, the "safer way" 43 and the doctrine was called "tutiorism".

In practice, the clearly more benevolent probabilists soon incurred the charge of "laxists", combining the critique by protestants with the criticism from within the Catholic Church itself. The truly fatal blow to casuistry was allegedly delivered by the famous Blaise Pascal in his Lettres Provinciales (1656-57). ${ }^{44}$ From then onwards, casuistry was gradually abandoned even within the Catholic Church itself (albeit this only materialized to a full extent in the 19th and 20th centuries).

Still, remnants of probabilism survived even after its critique by Blaise Pascal - however, in an amended form which gave priority to law before the subjective moral judgment (e.g. in the works by François Genet). A temporary revival of casuistry was then once again brought about by St. Alphonsus de Liguori (1696-1787) in his Theologia moralis (1753-1755), where

\footnotetext{
40 Delumeau, op. cit., note 37.

41 Decock, Theologians, op. cit., note 33, pp. 44-49.

42 Ibid.

43 The shift from tutiorism to probabilism is being attributed to Jesuits. See Maryks, R. A., From Medieval Tutiorism to Modern Probabilism: "Spoils of Egypt" and the Making of the Jesuit Conscience from Loyola to Pascal, Fordham University, New York, 2005, p. vi. 
he newly introduced the casuistic doctrine of equiprobabilism to make good for the flaws of probabilism. He namely claimed on one hand that truth should be given priority, just like the conscience is committed to respect rational moral judgments, but still the freedom of human beings should be observed where there is no clear priority of one of the possible options. ${ }^{45}$ At the same time, however, Liguori also claimed that the law which is uncertain or unclear, is not binding. Nevertheless, his ideas anyway took roots only in the end of the 19th century, when the casuistry was already dying out for good. Until its very end, however, various forms of casuistry on a scale between tutiorism and probabilism were discussed and defended throughout the centuries. These can be summarized here as follows:

1. Absolute tutiorism, under which freedom to act is at hand only if there is absolute certainty that there is nothing that prohibits the planned acting. This too rigorous doctrine was repudiated by Pope Alexander VIII. by the end of the 17 th century.

2. Mixed tutiorism - ordering the decision-maker to halt at every possible opinion to the contrary - meaning the person should not act if there is a possible contradictory opinion.

3. Probabiliorism - being a more benevolent teaching, it allowed to act in situations where subjective judgment was perceived more probable and more correct than the law (or the competing opinion).

4. Compensationism (a form of probabilism) - allowing for freedom of acting, while not requiring any qualified probability of correctness with respect to the given law or competing opinion. ${ }^{46}$ Just a simple probability of the choice being correct gave it priority before the law.

5. Laxism, being a counterpoint to absolute tutiorism. To consider law binding, it was to be absolutely certain. Otherwise it is not binding and acting in any other way is permitted. This teaching was repudiated by Pope Innocent XI. back in 1591.

6. Finally, equiprobabilism was applicable in situations where there were two or more equally acceptable judgments possible. Should a person hesitate (be in doubts), they should resist from acting (e.g. as in case of "in dubio pro reo" principle in criminal law).$^{47}$

Having already mentioned the close relationship between moral theology/casuistry and law, one might not wonder that theologians themselves, e.g. Soto, often used in their works an example of a judge, deciding in uncertainty, to discuss the above theories. Thus, according to Soto, "a judge may argue for a less probable juridical opinion in academic debate", but "he must prefer the more probable side in court" ${ }^{48}$ On the other hand, Medina, according to Schüssler: "as-

45 Hrehová, H., Základy morálnej teológie v dejinnom kontexte I. (Od jej počiatkov po tridentskú reformu). (Fundamentals of moral theology in historical context I.), Masarykova univerzita, Brno, 2012, p. 258-259.

46 This was a misreading of original ideas of Medina on probabilism - "preference for security was considered a duty in medieval theories of moral decision-making in uncertainty, but only in cases with equally strong reasons for all alternatives. Assuming that one opinion is more probable than another precludes this situation. As a result, Medina did not need to mention security in his formula of probabilism. Later probabilists, however, explicitly assumed that a probable opinion might be preferred to a more probable and safer one". See Schüssler, R., On the Anatomy of Probabilism. In: Kraye, J.; Saarinen, R. (eds.), Moral Philosophy on the Threshold of Modernity, Springer, Dordrecht, 2005, p. 93.

47 Hrehová, op. cit., note 45, p. 261.

48 Schüssler, op. cit., note 46, p. 94. 
sumes that a judge may prefer the less probable side even in court, as long as it is probable. But note that he restricts his solution to those cases where probability is not entirely based on objective testimony. It may also be based, for example, on juristic commentaries or on a survey of expert opinion. In these cases, a judge may follow a less probable opinion. There seem to be two possible motivations for such a decision. The judge can prefer a less probable opinion himself, going against a majority of authorities. Or he may be influenced by political, institutional or economic pressures to embrace the less probable side. Both kinds of motivation can be found in probabilistic analyses of cases of conscience. Consequently, probabilism not only diminished the burden of information-gathering costs but also enabled decision-makers to exploit differences between their own opinions and those of others with relevant expertise. In this way, probabilism considerably increased the flexibility of moral choice." 49

However, the flexibility might also take the judge too far, especially since later the laxist "lex dubia" principle ("lex dubia non obligat") became popular, assuming that "a law or an obligation of doubtful validity is not binding. In other words, no one has to follow a moral rule or to honour an obligation whose validity or existence remains doubtful." ${ }^{50}$ This version of laxism authored by Francisco Suárez was the most heavily criticized.

As a pendant to probabilism, a "very radical doctrine of risk-aversion in decision-making", ${ }^{51}$ referred to as modern (absolute) tutiorism soon emerged. Blaise Pascal and other opponents of probabilism were themselves representatives of this sort of tutiorists, their modern version being different from the medieval tutiorism. In the Middle Ages, tutiorism namely only applied if there was actual doubt (dubium) present, meaning uncertainty between two alternative options - in that case the safer (tutior) option was to be followed. In contrast, "the tutiorism of the later 17th century called for risk-aversion in all cases of uncertainty. Therefore, it was far more radical than its medieval predecessor. Indeed, it was so radical that it found very few proponents apart from the Jansenists and their followers." ${ }^{2}$

To conclude, the classification scheme which begins with (absolute) tutiorism and then goes on through probabiliorism to probabilism and finally ends up with soft-probabilism (compensationism and laxism), reflects the situation after the Thirty Years War. Until then, both strict tutiorism and soft-probabilism were unknown.

As a sort of compromise, the new doctrine, called equiprobabilism, was to provide an answer and solution to the disputes in modern times. Equiprobabilism in the version of de Liguori namely proposed that an opinion is "to be preferred if it is considerably more probable than its counter-opinion." 53 However, "if the probability of two rival opinions is only slightly different, the less probable opinion may also be chosen". ${ }^{54}$ Albeit being attributed to Liguori, in fact, Christoph Rassler seems to be the one who invented this sort of equiprobabilism in the book Norma recti

\footnotetext{
49 Ibid., p. 94.

50 Ibid., p. 103.

51 Curran speaks of "a sharp discussion between the two extremes of laxism and rigorism". Curran, C. E., Catholic Moral Theology in the United States : A History, Georgetown University Press, Washington, D.C., 2008, p. 3.

52 Ibid

53 Equiprobabilists "measured degrees of difference in probability in terms of psychic inclination towards assent. This inclination was treated like a kind of quantitative physical force which resulted from weighing the evidence. No aleatoric reasoning was employed to justify the weighing up." Schüssler, op. cit., note 46, pp. 109-110. 
(1713). This idea was then adopted by Eusebius Amort and finally embraced by Alphonsus de Liguori, who in the end of the day became known as the author of the doctrine of equiprobabilism. ${ }^{55}$ This version of casuistry became popular precisely due to the fact that it was a mixture of probabilism and probabiliorism, allowing for a certain degree of free choice. However, at the same time this meant the end the quasi-juridical character of casuistry, to return again only with Bentham and Kant - however, not being based on the casuistic idea of law, but rather giving precedence to utilitarian consequentialism or to deontologic principlism. ${ }^{56}$ Casuistry started to be considered instead as "the art of deliberate wrongdoing, the art of twisting the laws", thereby "ruining the general principle of social life", while in addition being "incompatible with the erection of a bourgeois society grounded in justice and morality". ${ }^{57}$

Still, one might legitimately ask whether we still live in a bourgeois society grounded in formalist values of the 19th century or rather in a post-modern and post-positivist era where casuistry might again prove being of value... This is where we finally get to the main argument of this paper.

\section{ON THE USE OF MORAL CASUISTRY IN POST-POSITIVIST LEGAL THOUGHT}

Rudolf Schüssler claims that "today, probabilism is familiar only to a few specialists in moral theology and early modern casuistry", ${ }^{58}$ but considers this neglect unwarranted. He proposes that contemporary ethics should restore probabilism to its former prominence. ${ }^{59}$ But which sort of probabilism should be followed nowadays - laxism, compensationism, probabiliorism, or finally the equiprobabilism of St. Alphonsus de Liguori? Or should we instead prefer one of the versions of tutiorism?

Alexander Nikolaevich Shytov proposed already in 2001 to take the path of probabilism (in general), when he analysed the theory of Kenneth Kirk, who successfully "tried to combine theological and legal approaches" ${ }^{60}$ His work Conscience and Its Problems ${ }^{61}$ is therefore considered by Shytov a very useful tool in explaining modern judicial casuistry, while resting on the Aristotelian traditions: "Equity is a correction of the law. Every law is expressed in general terms, and there are some matters which cannot be accurately dealt with in general terms .... In such cases the law lays down what is right for the majority of cases, without loosing sight of the consequent inaccuracy - an inaccuracy which springs neither from the law nor from legislator, but from the nature

\footnotetext{
55 Ibid., pp. 108-109.

56 Ibid., p. 110.

57 Kittsteiner, H.-D., Kant and casuistry. In: Leites, E. (ed.), Conscience and Casuistry in Early Modern Europe, Cambridge University Press, Cambridge, 1988, p. 190.

58 And mostly is evaluated negatively. See Fleming, J., Defending Probabilism: The Moral Theology of Juan Caramuel, Georgetown University Press, Washington, D.C., 2006.

59 Schüssler, op. cit., note 46, p. 91.

60 Shytov, A. N., Conscience and Love in Making Judicial Decisions, Springer, Dordrecht, 2001, p. 79 ff.

61 Kirk, K., Conscience and Its Problems, Longmans, London, 1933. See also Kirk, K. E., Some principles of moral theology and their application, Longmans, Green and co., London, 1920.
} 
of the case, as an inevitable condition of human action. When, therefore, a law is laid down generally, but manifest ground for exception appears in a particular case, it is right that failure of the legislator should be made good exactly as he would make it good if he were present, or would amend his law if he took the case into account." 62 In legal theory, this operation is known nowadays as teleological reduction, or sometimes it goes under the headline of axiological gaps.

Thereby, under Kirk (and Shytov), in the situation where one has "to apply a law which seems to be unjust in a particular situation, they are advised - in order to escape the open conflict and disobedience - to look for the exceptions" or "to undertake detailed scrutiny of the formula in which the law is expressed. The purpose of such a scrutiny is adjusting and factual amendment of the law" ${ }^{63}$ Hence, the law can be considered defeasible, while it is necessary to find the legally most relevant way to circumvent the law - outright rejection of the law (i.e. deciding contra legem) based only on moral arguments being the most extreme (but still acceptable) move... When comparing this version of probabilism as proposed by Kirk with the modern-day legal practice, a question arises immediately: are nowadays all our activist judges in fact casuists and probabilists, even without knowing this?

Still, according to Shytov, the problem with all the schools of casuists - equiprobabilism, probabiliorism, probabilism (compensationism, laxism), or (absolute and mixed) tutiorism was "that they tried to formulate a formal principle which would allow them to solve cases of conscience" ${ }^{44}$ by following specific formulas. Even in current legal theory one also notices the same search for formulas to help the judges in choosing the appropriate solution, just as various schools of casuistry did - thus, Robert Alexy developed his quasi-mathematical formulas, Beyleveld and Brownsword formulated the "principle of generic consistency", ${ }^{65}$ Dworkin designed the "principle of integrity", ${ }^{66}$ and Posner endorsed "efficiency" principle, ${ }^{67}$ all of these in fact promoting a different type of modern legal casuistry (sic!).

However, the general approach underlying any casuistic theory should thereby be that of a doubt whether any precise guideline for the search for justice (be it probabilism or tutiorism) can ever be designed...

\section{CASUISTRY, VIRTUE ETHICS AND COGNITIVE SCIENCE : AN OUTLINE OF NEW LEGAL CASUISTRY}

As a sort of the rule of the thumb, probabilism in all its forms may be advocated for as a (both descriptive and prescriptive) model for present-day legal decision-making. At the same time, however, this practice is causing the rise of legal uncertainty. The quest for legal certain-

\footnotetext{
62 Kirk, Conscience, op. cit., note 61, p. 126.

63 Shytov, op. cit., note 60 , p. 80.

64 Ibid., p. 82.

65 Beyleveld, D.; Brownsword, R., Law as a Moral Judgement, Sweet \& Maxwell, London, 1986.

66 Dworkin, R., Law's Empire, Harvard University Press, Cambridge, 1986.

67 Posner, R., Economic Analysis of Law, Little, Brown and Company, Toronto, 1992.
} 
ty thus forces us to search for limits of the probabilist approach to legal (and especially judicial) decision-making. Still, the recent trends known as virtue ethics and virtue jurisprudence claim that limits of decision-making very much depend solely on the person and personality of the decision-maker. Both casuistry and virtue ethics (as well as virtue jurisprudence) namely operate under a similar premise recognized also by cognitive scientists, namely that the ability to decide and chose well is learned and depending on specific social contexts. ${ }^{68}$ This creates the limits and boundaries of the decision-making. The suggestion thereby is that legal "practical sense", serving to decide a case, is attained mostly through professional experience - expertise. Expertise has thereby been defined as the ability to solve problems efficiently and accurately, usually resting on two factors: a) the amount of knowledge and b) the quality of its organization. Put simply, knowing more does not make an expert. The distinguishing mark of an expert is the ability to organize one's knowledge in ways that permit to recognize patterns and retrieve information from the pool efficiently. This allegedly often requires "chunking" groups of information together and storing them in mental models with high levels of abstraction. ${ }^{69}$

This is the case also when solving legal problems - even in the traditional (systematic) approach to problem-solving it is namely common to use the expertise acquired through experience - either in the form of an intuitive fast-thinking (which can, however, be negatively influenced by cognitive biases), or in the form of slow thinking, taking form of applying chunks of knowledge in the form of organized pool of maxims and paradigms in order to reach a best fitting (and just) solution of the case at hand. This hypothesis of working with the "practical sense" and "practical wisdom", being acquired by expertise, thus in fact reconciles the systematic (top-down) with the casuistic (bottom-up) approach to problem-solving, showing there is not much difference at the cognitive level when using the two different paradigmatic approaches (at least upon reaching a certain level of expertise in legal decision-making). This is also another argument for the combination of principlist and casuistic approach we advocate for in this paper to explain (descriptively) how legal decision-making in daily judicial practice actually works. In addition, taken prescriptively, in "hard cases" of new legal challenges not regulated satisfactorily by prior laws or principles, the paradigmatic approach of casuistry seems to be more efficient to provide a solution to the case at hand - albeit without any direct step-by-step guidance, and, in fact, interestingly using similar cognitive operations as when solving a case within the systematic (principlist, formalist) paradigm.

\section{CONCLUSION}

Legal casuistry was abandoned in Europe in the Enlightenment period, when specifically laxist moral casuists of Catholic Church were often accused of being able to pardon even a murder, based on the subtle arguments voiced in their manuals. ${ }^{70}$ Casuistry was neverthe-

68 Calkins, M., Developing a Virtue-Imbued Casuistry for Business Ethics, Issues in Business Ethics, 42, 2014, p. $146 \mathrm{ff}$.

69 See Ericsson, K. A,; Smith, J., Toward a General Theory of Expertise: Prospects and Limits, Cambridge University Press, Cambridge, 1991; Cankorel, T., Cognitive Classification of Legal Principles: A New Approach to International Legal Training, Ankara Law Review, Vol. 5, No. 2, 2008, p. 171.

70 In a similar vein, lawyers and casuists were considered immoral. Cf. Romeo, A., Juristen, böse Christen (?). Religione e deontologia forense nella teoria del diritto, Stato, Chiese e pluralismo confessionale, n. 15, 2017. 
less historically very useful in resolving problems of conscience and in regulating human behaviour of believers - especially in cases when even the ancient Roman law failed to offer a solution to a legal problem. ${ }^{71}$ Interestingly, "the casuistic method has been widely adopted in the common law countries where the judges have had and continue to have more discretion in the administration of law, and where the principle of equity has been always respected. The place of abstract moral and legal principles in making judgements, attention to the circumstances, appeal to reason, different ways of interpretation of the established legal rules and new situations which were not envisaged by the lawgiver, all these have originated in the casuistic thinking." "The core of the casuistic method lies in the idea that general rules, whether religious or legal, should be applied in a flexible way. Circumstances affect the applicability of the rules. Casuistry gives more freedom to decision-makers to determine how far the application of rules matches particular situations." "73 The casuists even often tried to find an argument to follow a different path action than required by law. ${ }^{74}$ The usefulness of the method of casuistry was thus clear in situations where the agent had a discretion in selecting the facts, in choosing the rules, or in determining the solution to the dispute. ${ }^{75}$ Understandably, however, this sort of casuistic approach to law was not acceptable or desirable neither in the world of absolutist states and monarchs nor in the world of the positivist/formalist rule of (bourgeois) law in which an individual (including the judge) was to obey law without any discretion. ${ }^{76}$

Having here identified the reasons for downfall of casuistry, one should not wonder nowadays in the post-positivist era of postmodern doubts and crises of the legislative monopoly of states that the idea of casuistry resurfaces again. Nothing else than a reflection of the basic ideas of casuistry can namely be seen in the current "legal realist" view of axiological gaps in law and in the defeasibility of legal norms, ${ }^{77}$ as well as in the more traditional "teleological reduction" allowing for deciding contra legem. It is precisely the casuistry that provides a ground for interaction of legal and extra-legal (originally moral/theological) approaches, helping to find a way which allows an agent (the judge) to resolve a dispute in a fair and just way, allowing for the choice of a rule to follow and the final decision to be reached by the agent ${ }^{78}$ - the limitation thereby being the expertise gained by the respective agent throughout their education and training.

To conclude, a sort of new legal casuistry, building on early modern moral theology and its theories of casuistry introduced in this paper, might hence be advocated for as a useful tool to explain both descriptively the actual functioning of law in the current post-positivist era, as well as prescriptively to provide general guidelines to finding an acceptable solution to a hard case at hand. Surely, this paper could not have addressed all the implications of the proposed

71 Jonsen; Toulmin, op. cit., note 11, pp. 47, 52-53, 101, 113-121.

72 Shytov, op. cit., note 60, p. 75.

73 Ibid., p. 80. Just like in the medieval Satan's trial, where Satan was a legal formalist, while the Mother of God was a casuist - see Coulson, D., The Devil's Advocate and Legal Oratory in the Processus Sathanae, Rhetorica, Vol. XXXIII, Issue 4, 2015, pp. 409-430.

Shytov, op. cit., note 60, p. 78-79.

75 Ibid., p. 82.

76 Van Caenegem, R. C., Judges, Legislators and Professors : Chapters in European Legal History, Cambridge University Press, Cambridge, 1987, s. 152: "Codification was historically a weapon against the judiciary, or the caste of the noblesse de robe who owned their offices and invoked nebulous general principles that were nowhere written down." 
new legal casuistry; rather, it is to serve only as a history-laden contribution to the debate on the post-positivist situation in law and possibly as a starting point for discussions on the future of legal argumentation and decision-making.

\section{REFERENCES}

1. Aarnio, A., One Right Answer? In: Aarnio, A., Essays on the Doctrinal Study of Law, Springer, Dordrecht, 2011.

2. Barberis, M., El realismo jurídico europeo-continental. In: Fabra Zamora, J. L.; Núñez Vaquero, Á. (eds.), Enciclopedia de Filosofía y Teoría del Derecho, volumen uno, UNAM, Mexico, 2015.

3. Bedau, H. A., Making Mortal Choices. Three Exercises in Moral Casuistry, Oxford University Press, Oxford, 1997.

4. Berdisová, L., Objectivity and arbitrariness of blind rule-following or what it means to follow a (legal) rule blindly. In: Breda, V.; Rodak, L. (eds.), Diverse Narratives of Legal Objectivity: an interdisciplinary perspective, Peter lang, Frankfurt am Main, 2016, pp. 29-56.

5. Bergfeld, C., Katholische Moraltheologie und Naturrechtslehre. In: Coing, H. (ed.), Handbuch der Quellen und Literatur der neueren europäischen Privatrechtsgeschichte, Bd. II: Neuere Zeit (1500-1800). Das Zeitalter des gemeinen Rechts, Teilband I: Wissenschaft, C. H. Beck'sche Verlagsbuchhandlung, München, 1977, pp. 999-1033.

6. Berman, H., Law and Revolution II: The Impact of the Protestant Reformations on the Western Legal Tradition, Harvard University Press, Cambridge Mass., 2003.

7. Berman, H., Law and Revolution. The Formation of the Western Legal Tradition, Harvard University Press, Cambridge Mass., 1983.

8. Beyleveld, D.; Brownsword, R., Law as a Moral Judgement, Sweet \& Maxwell, London, 1986.

9. Bunge, K.; Fuchs, M. J.; Simmermacher, D.; Spindler, A. (eds.), The Concept of Law (lex) in the Moral and Political Thought of the 'School of Salamanca', Brill, Leiden, 2016.

10. Calkins, M., Developing a Virtue-Imbued Casuistry for Business Ethics, Issues in Business Ethics, 42, 2014, p. $146 \mathrm{ff}$.

11. Cankorel, T., Cognitive Classification of Legal Principles: A New Approach to International Legal Training, Ankara Law Review, Vol. 5, No. 2, 2008.

12. Champeil Desplats, V., Michel Troper (1938- ). In: Pattaro, E.; Roversi, C. (eds.), A Treatise of Legal Philosophy and General Jurisprudence. Volume 12. Legal Philosophy in the Twentieth Century: The Civil Law World, Springer, Dordrecht, 2016, p. $447 \mathrm{ff}$.

13. Coulson, D., The Devil's Advocate and Legal Oratory in the Processus Sathanae, Rhetorica, Vol. XXXIII, Issue 4, 2015, pp. 409-430.

14. Curran, C. E., Catholic Moral Theology in the United States : A History, Georgetown University Press, Washington, D. C., 2008.

15. Dari-Mattiacci, G.; Deffains, B., Uncertainty of Law and the Legal Process, Journal of Institutional and Theoretical Economics, 163, 2007.

16. David, J. E., Jurisprudence and Theology in Late Ancient and Medieval Jewish Thought, Springer, Cham, 2014

17. Decock, W., From Law to Paradise: Confessional Catholicism and Legal Scholarship, Rechtsgeschichte, 18, 2011. 
18. Decock, W., Jesuit Freedom of Contract, The Legal History Review, 77, 2009, pp. 423-458.

19. Decock, W., Theologians and Contract Law: The Moral Transformation of the Ius Commune (ca. 15001650), Brill, Leiden, 2014.

20. Delumeau, J., Sin and Fear: The Emergence of the Western Guilt Culture, 13th-18th Centuries, Palgrave Macmillan, London, 1990.

21. Dworkin, R., Law's Empire, Harvard University Press, Cambridge, 1986.

22. Ericsson, K. A.; Smith, J., Toward a General Theory of Expertise: Prospects and Limits, Cambridge University Press, Cambridge, 1991.

23. Ferrer Beltrán, J.; Ratti, G. B. (eds.), El realismo jurídico genovés. Marcial Pons, Madrid, 2011.

24. Fleming, J., Defending Probabilism: The Moral Theology of Juan Caramuel, Georgetown University Press, Washington, D. C., 2006.

25. Flyvbjerg, B., Making Social Science Matter: Why Social Inquiry Fails and How It Can Succeed Again, Cambridge University Press, Cambridge, 2001.

26. Glučina, I., Michel Troper i francuski pravni realizam. In: Zbornik radova Pravnog fakulteta u Splitu, god. 53, 3/2016, pp. 777-796.

27. Guastini, R., A Sceptical View on Legal Interpretation. In: Analisi e diritto 2005. Giappichelli, Turin, 2006.

28. Guastini, R., Defettibilità, lacune assiologiche, e interpretazione, Revus, 14, 2010.

29. Hrehová, H., Základy morálnej teológie v dejinnom kontexte I. (Od jej počiatkov po tridentskú reformu). (Fundamentals of moral theology in historical context I.), Masarykova univerzita, Brno, 2012.

30. Jonsen, A. R.; Toulmin, S., The Abuse of Casuistry: A History of Moral Reasoning, University of California Press, Berkeley, 1988.

31. Kirk, K. E., Some principles of moral theology and their application, Longmans, Green and co., London, 1920.

32. Kirk, K., Conscience and Its Problems, Longmans, London, 1933.

33. Kittsteiner, H.-D., Kant and casuistry. In: Leites, E. (ed.), Conscience and Casuistry in Early Modern Europe, Cambridge University Press, Cambridge, 1988.

34. Lang, M., Legal uncertainty as a welfare enhancing screen, European Economic Review, 91, 2017.

35. Likhovski, A., Protestantism and the rationalization of English Law: A Variation on a Theme by Weber, Law \& Society Review, 1999, 33, 2, p. 365 ff.

36. Maryks, R. A., From Medieval Tutiorism to Modern Probabilism: "Spoils of Egypt" and the Making of the Jesuit Conscience from Loyola to Pascal, Fordham University, New York, 2005.

37. Mausen, Y.; Condorelli, O.; Roumy, F.; Schmoeckel, M. (eds.), Der Einfluss der Kanonistik auf die europäische Rechtskultur, Bd. 4: Prozessrecht, Böhlau Verlag, Köln, 2014.

38. Paulo, N., Casuistry as common law morality, Theor Med Bioeth, 36, 2015.

39. Paulo, N., The Confluence of Philosophy and Law in Applied Ethics, Palgrave Macmillan, London, 2016.

40. Posner, R., Economic Analysis of Law, Little, Brown and Company, Toronto, 1992.

41. Romeo, A., Juristen, böse Christen (?). Religione e deontologia forense nella teoria del diritto, Stato, Chiese e pluralismo confessionale, n. 15, 2017.

42. Roumy, F.; Schmoeckel, M.; Condorelli, O. (eds.), Der Einfluss der Kanonistik auf die europäische Rechtskultur, Bd. 2: Öffentliches Recht, Böhlau Verlag, Köln, 2011.

43. Schmoeckel, M., Das Gesetz Gottes als Ausgangspunkt christlicher Ethik? Zu calvinistischen Traditionen des 16. Jhs im Hinblick auf ihre rechtshistorische Relevanz, Ius commune, 25, 1998, pp. 347-366. 
44. Schmoeckel, M., Die katholische Wissenschaft. Die methodische Säkularisation der Jurisprudenz im 16. Jahrhundert. In: Büttgen, P.; Imbach, R.; Schneider, U. J.; Selderhuis, H. J. (eds.), Vera Doctrina. Zur Begriffsgeschichte der Lehre von Augustinus bis Descartes, Harrassowitz Verlag, Wiesbaden, 2009, pp. 167-171.

45. Schmoeckel, M.; Condorelli, O.; Roumy, F. (eds.), Der Einfluss der Kanonistik auf die europäische Rechtskultur. Bd. 1: Zivil- und Zivilprozessrecht, Böhlau Verlag, Köln, 2009.

46. Schmoeckel, M.; Condorelli, O.; Roumy, F. (eds.), Der Einfluss der Kanonistik auf die europäische Rechtskultur, Bd. 3: Straf- und Strafprozessrecht, Böhlau Verlag, Köln, 2012.

47. Schröder, J., Recht als Wissenschaft : Geschichte der juristischen Methodenlehre in der Neuzeit (15001933), 2nd ed., C.H.Beck, München, 2012.

48. Schüssler, R., On the Anatomy of Probabilism. In: Kraye, J.; Saarinen, R. (eds.), Moral Philosophy on the Threshold of Modernity, Springer, Dordrecht, 2005.

49. Shytov, A. N., Conscience and Love in Making Judicial Decisions, Springer, Dordrecht, 2001.

50. Sinai, Y.; Golding, M. P., Is there only One Correct Legal Answer to a Question of Fact? Three Talmudic Answers to a Jurisprudential Dilemma, Ratio Juris, Vol. 29, No. 4, 2016, pp. 478-505.

51. Van Caenegem, R. C., Judges, Legislators and Professors: Chapters in European Legal History, Cambridge University Press, Cambridge, 1987.

52. Weber, M., The Protestant Ethic and the Spirit of Capitalism, Routledge, London and New York, 1992.

53. Whitman, J. Q., The origins of reasonable doubt, theological roots of the criminal trial, Yale University Press, New Haven, London, 2008.

54. Witte, J., Law and Protestantism: The Legal Teachings of the Lutheran Reformation, Cambridge University Press, Cambridge, 2002. 
Tomáš Gábriš

\section{USKLAĐENOST I POŠTOVANJE PROPISA U UVJETIMA PRAVNE NESIGURNOSTI: NOVA PRAVNA KAZUISTIKA POTAKNUTA TEOLOGIJOM}

\section{Sažetak}

U Europi se suvremena teorija kazuistike u posljednje vrijeme nije osobito razvijala niti joj se posvećivala velika pozornost u pravnoj znanosti od 50-ih godina 20. stoljeća kada je Viehwegov pokušaj ponovnog uvođenja kazuističkog (topičkog) pristupa doživio neuspjeh. Ipak, problemi vezani uz ovu temu nisu nestali te se i danas mnogi pravni stručnjaci (odvjetnici i suci) i dalje suočavaju s istim dilemama s kojima su se suočavali i srednjovjekovni ispovjednici i kazuisti. Ovaj rad se u tom smislu bavi pitanjem može li bilo koja nova čvrsta teorija pravne kazuistike, koja se temelji bilo na kazuistici kojom se koriste teolozi i ispovjednici ili na kazuistici kojom se danas koriste etičari, posebice u bioetičkim znanostima, koristiti pravnim stručnjacima kontinentalnog prava koji su naviknuti na sustavno umjesto na kazuističko razmišljanje, a koji i nadalje sumnjaju u teoriju jedinog točnog odgovora ili se nalaze u situaciji pravne nesigurnosti zbog bilo kojeg razloga.

Ključne riječi: $\quad$ teme, kazuistika, moralna teologija, usklađenost, nesigurnost

\section{(c) (i) (5)}

This work is licensed under a Creative Commons

Attribution-NonCommercial 4.0 International License.

Prof. dr. sc. Tomáš Gábriš, istraživač, Slovačka akademija znanosti, Institut za državu i pravo, Klemensova 19, 81364 Bratislava, Republika Slovačka. Adresa e-pošte: gabris.tomas@gmail.com. ORCID: https://orcid.org/0000-0002-6862-2688. 